\title{
The role of dietary protein in hepatic lipogenesis in the young rat
}

\author{
BY G. R. HERZBERG AND MINDA ROGERSON \\ Department of Biochemistry, Memorial University of Newfoundland, St John's, \\ Newfoundland AlB $3 \times 9$ Canada
}

(Received 30 July 1980 - Accepted 27 October 1980)

\begin{abstract}
1. The effect of varying dietary levels of casein $(40-140 \mathrm{~g} / \mathrm{kg})$ on hepatic lipogenesis and the levels of hepatic fatty acid synthetase (FAS), glucose-6-phosphate dehydrogenase (EC 1.1.1.49; G6PD), malic enzyme (EC 1.1.1.40; ME), citrate cleavage enzyme (EC 4.1.3.8; CCE), acetyl CoA carboxylase (EC 6.4 1.2; AcCx), glucokinase ( $E C$ 2.7.1.2; GK), and pyruvate dehydrogenase (PDH) was examined in young, growing rats.

2. The activities of AcCx, FAS, G6PD and in vivo fatty acid synthesis were generally found to increase with increased dietary protein.

3. The levels of GK and PDH were not related to dietary protein.

4. ME decreased with increasing dietary protein.

5. The results demonstrate a dissociation between hepatic fatty acid synthesis and ME and suggest that when rats consume low-protein diets the NADPH needed for fatty acid synthesis is generated primarily by ME but that as the level of dietary protein is increased the contribution of $\mathrm{ME}$ is reduced while that of the phosphogluconate pathway becomes more important.
\end{abstract}

The role of dietary composition in the regulation of fatty acid synthesis has been extensively studied. Both the composition and level of carbohydrate, fat and protein have been demonstrated to regulate the rate of fatty acid synthesis and the activities of a number of associated enzymes (Romsos \& Leveille, 1974a).

Increasing the amount of dietary fat has been reported to depress liver fatty acid synthesis. This effect is due to a specific inhibitory effect of fat and not only to the accompanying reduction in carbohydrate intake (Hill et al. 1960). It has been demonstrated that in liver, but not adipose tissue, polyunsaturated fatty acids are more inhibitory than are saturated fatty acids. These effects are observed in vivo and in vitro and the effects on fatty acid synthesis are paralleled by changes in the activities of fatty acid synthetase (FAS), acetyl CoA carboxylase (EC 6.4.1.2; AcCx); citrate cleavage enzyme (EC 4.1.3.8; CCE); malic enzyme (EC 1 1 1 1 .40; $\mathrm{ME})$ and glucose-6-phosphate dehydrogenase (EC 1 1 1 1 .49; 66PD) (Clarke et al. 1977a, b, $c$; Triscari et al. 1978).

Increasing dietary carbohydrate results in increased fatty acid synthesis and increased activities of the associated enzymes (Romsos \& Leveille 1974a). As with dietary fat, the type of carbohydrate affects the fatty acid synthetic activity of liver. The rate of synthesis has generally been found to be greatest for fructose, less for sucrose and lowest for glucose and starch (Romsos \& Leveille, 1974a, b; Bruckdorfer et al. 1972).

The role of dietary protein in the regulation of fatty acid synthesis has been studied much less than either fat or carbohydrate. Yeh \& Leveille (1969) reported a decrease in chicken liver lipogenesis with increasing dietary protein. This was accompanied by a decrease in $\mathrm{ME}$. Peret et al. (1975) found a decrease in rat liver ME with increasing dietary protein. Stark et al. (1975) were unable to find any correlation between rat liver ME and lipogenesis under conditions of protein deprivation.

The experiments reported in this paper were conducted to study the role of dietary protein in the regulation of hepatic fatty acid synthesis and the levels of several associated enzymes in the young, growing rat. 


\section{EXPERIMENTAL}

Male weanling Sprague Dawley rats obtained from Canadian Breeding Labs, LaPrairie, Quebec, were used. The average weight of the rats was $55.1 \mathrm{~g}$ on the first day of the experiment. The rats were distributed so that each treatment group had a similar initial average body-weight. Four rats were included in each treatment group. The animals were maintained in a light-controlled (lights on $09.00-21.00$ hours) room at a temperature of approximately $23^{\circ}$. Food and water were available ad lib. The animals were housed individually in metabolic cages. The composition of the diets is given in Table 1. The animals were fed for $28 \mathrm{~d}$.

Table 1. Composition $(\mathrm{g} / \mathrm{kg})$ of the experimental diets

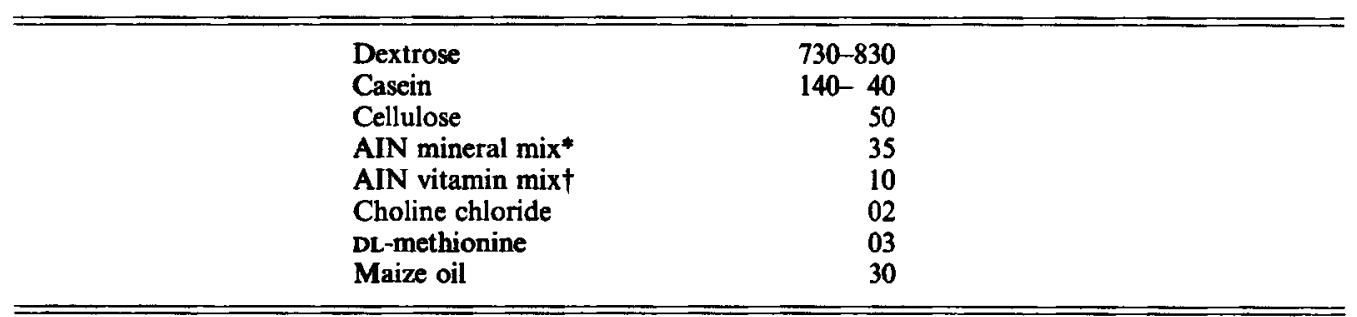

- Obtained from ICN Nutritional Biochemicals, Cleveland, Ohio has the following composition $(\mathrm{g} / \mathrm{kg})$ : $\mathrm{CaHPO}_{4}, 500 ; \mathrm{NaCl}, 74.0 ;$ potassium citrate monohydrate, $220 \cdot 0 ; \mathrm{K}_{2} \mathrm{SO}_{4}, 52 \cdot 0, \mathrm{MgO}, 24 \cdot 0 ; \mathrm{MnCO}_{3}, 3 \cdot 5 ;$ ferric citrate, $6.0 ; \mathrm{ZnCO}_{3}, 1.6 ; \mathrm{CuCO}_{3} ; \mathrm{KIO}_{3}, 0.01 ; \mathrm{Na}_{2} \mathrm{SeO}_{3} .5 \mathrm{H}_{2} \mathrm{O}, 0.01 ; \mathrm{CrK}\left(\mathrm{SO}_{4}\right)_{2} .12 \mathrm{H}_{2} \mathrm{O}, 0.55 ;$ sucrose, 118.0 .

† Obtained from ICN Nutritional Biochemicals, Cleveland, Ohio, has the following composition $(/ \mathrm{kg})$ : thiamine hydrochloride $600 \mathrm{mg}$, riboflavin $600 \mathrm{mg}$, pyridoxine hydrochloride $700 \mathrm{mg}$, nicotinic acid $3 \mathrm{mg}$, calcium-D pantothenate $1.6 \mathrm{mg}$, folic acid $200 \mathrm{mg}$, D-biotin $20 \mathrm{mg}$, cynaocobalmin $1 \mathrm{mg}$, retinyl palmitate $800 \mathrm{mg}$, DL- $\alpha$-tocopheryl acetate $20 \mathrm{~g}$, cholecalciferol $2.5 \mathrm{mg}$, menaquinone $5.0 \mathrm{mg}$, sucrose $972.9 \mathrm{~g}$.

On the morning of the 29th day, the animals were injected intraperitoneally with $500 \mu \mathrm{Ci}^{3} \mathrm{H}_{2} \mathrm{O}$ and were decapitated $60 \mathrm{~min}$ later. A sample of blood was taken for determination of plasma specific radioactivity. The liver was rapidly removed and a portion homogenized in cold $0.15 \mathrm{M}$-potassium chloride, $1.0 \mathrm{~mm}$-magnesium chloride, $0.5 \mathrm{~mm}$ dithiothreitol and $10 \mathrm{~mm}-\mathrm{N}$-acetyl cysteine buffer, $\mathrm{pH} 7 \cdot 6$. Following centrifugation at $100000 \mathrm{~g}$ for $40 \mathrm{~min}$ the supernatant fraction was used for measurements of enzyme activities. FAS was determined by following the rate of malonyl-CoA-dependent-NADPH oxidation (Gibson \& Hubbard, 1960); G6PD from the rate of glucose-6-phosphate-dependent reduction of NADP (Lohr \& Walker, 1971); ME from the rate of malate-dependent NADP reduction (Yeh et al. 1970); glucokinase (EC 2.7.1.2; GK) from the rate of glucose-dependent reduction of NADP in the presence of added G6PD after correction for hexokinase (EC 2.7.1 1) activity (Pilkis, 1975); CCE by the method of Srere (1959) and $\mathrm{AcCx}$ from the acetyl CoA-dependent incorporation of $\mathrm{H}^{14} \mathrm{CO}_{3}{ }^{-}$into acid-stable material (Gove \& Hems, 1978).

A second fraction of the liver was homogenized in $10 \mathrm{~mm}$-potassium phosphate buffer, $\mathrm{pH} 7 \cdot 4$, containing $1 \mathrm{~mm}$-EDTA, $1 \mathrm{~mm}$-dithiothreitol and bovine serum albumin $(10 \mathrm{~g} / \mathrm{l})$. Pyruvate dehydrogenase (PDH) was converted to the fully-active form by preincubating for $30 \mathrm{~min}$ at $30^{\circ}$ in the presence of $10 \mathrm{~mm}$-magnesium chloride (Walajtys et al. 1974). PDH activity was determined from the rates of decarboxylation of $\left[{ }^{14} \mathrm{C}\right]$ pyruvate (Taylor $e t$ al. 1973).

A third portion of the liver was used to determine fatty acid synthesis in vivo (Lowenstein et al. 1971). The tissue was deposited directly into $5 \mathrm{M}$-potassium hydroxide and heated at $70^{\circ}$ for 3-4 h. After saponification, the samples were extracted with three $5 \mathrm{ml}$ portions of light petroleum (b.p. $37 \cdot 8-56 \cdot 1^{\circ}$ ) to remove non-saponifiable material. The samples were 
then acidified with hydrochloric acid and the fatty acids extracted with three $5 \mathrm{ml}$ portions of light petroleum (b.p. 37-8-56-1). The extracts were combined in a scintillation vial, the light petroleum evaporated and the radioactivity in the extracted fatty acids determined by liquid-scintillation spectrometry. Protein was determined by the microBiuret method of Goa (1953) using bovine serum albumin as standard.

Significance of a treatment effect was determined by analysis of variance (Steel \& Torrie, 1960). A treatment was considered significant at $P<0.05$.

\section{RESULTS}

The results of the experiments are illustrated in Figs. 1-9. Fig. 1 illustrates the growth rate as a function of dietary protein in the diet. The growth rate was linear for the $28 \mathrm{~d}$ feeding period. The growth rate increased with the increase in dietary protein up to $100 \mathrm{~g}$ protein $/ \mathrm{kg}$. From 100 to $140 \mathrm{~g}$ protein $/ \mathrm{kg}$ the growth rate was unchanged.

The results of the determination of fatty acid synthesis (in vivo) and the enzymes measured can be divided into three types of responses; those which tended to increase with increasing protein, those which tended to decrease with increasing protein and those which showed no correlation with dietary protein.

Fatty acid synthesis (in vivo) (Fig. 2) increased nearly fivefold from 40 to $120 \mathrm{~g}$ protein $/ \mathrm{kg}$ and declined at $140 \mathrm{~g}$ protein/ $\mathrm{kg}$ in the diet. FAS activity (Fig. 3) increased from 40 to $100 \mathrm{~g} / \mathrm{kg}$ dietary protein, there was an unexplained drop at the $120 \mathrm{~g} / \mathrm{kg}$ protein level and the $140 \mathrm{~g} / \mathrm{kg}$ level was nearly the same as that at $100 \mathrm{~g} / \mathrm{kg}$ protein. AcCx activity (Fig. 4) increased up to the $100 \mathrm{~g}$ protein $/ \mathrm{kg}$ level and declined sharply at higher protein levels.

CCE activity (Fig. 5) approximately doubled as the dietary protein was increased from 40 to $100 \mathrm{~g} / \mathrm{kg}$ and declined slightly at higher protein levels. G6PD activity (Fig. 6) more than doubled as the dietary protein was increased from 40 to $140 \mathrm{~g} / \mathrm{kg}$. ME activity (Fig. 7) decreased by $75 \%$ as the dietary protein was increased from 40 to $140 \mathrm{~g} / \mathrm{kg}$.

GK activity (Fig. 8) declined slightly (approximately $20 \%$ ) but not significantly from 40 to $100 \mathrm{~g}$ protein/kg. PDH activity (Fig. 9) was unrelated to the levels of dietary protein.

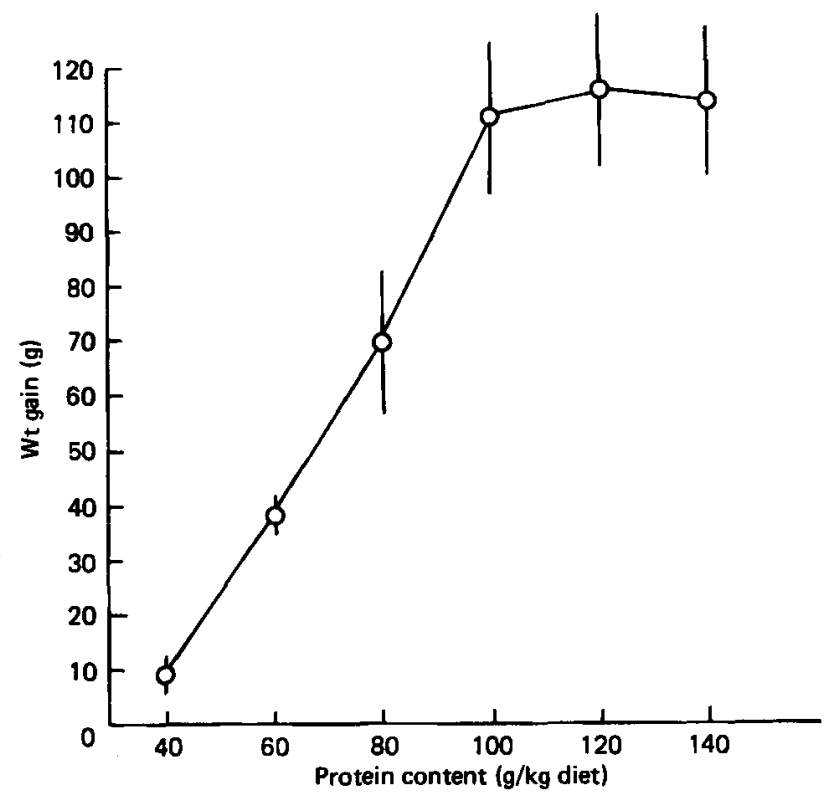

Fig. 1. The effect of dietary protein content $(\mathrm{g} / \mathrm{kg})$ on rat weight gain $(\mathrm{g})$. Weanling rats were given diets containing the indicated protein content for $28 \mathrm{~d}$ and their weight gain determined. Values are means from four rats with their standard errors represented by vertical bars. 


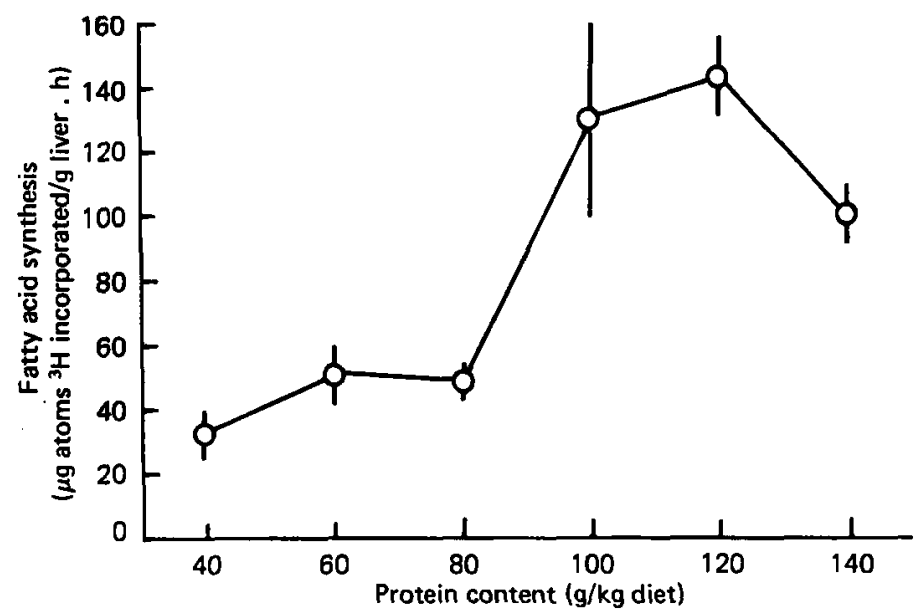

Fig. 2. Fatty acid synthesis in vivo ( $\mu \mathrm{g}$ atoms ${ }^{3} \mathrm{H}$ incorporated into fatty acids/g liver per $\mathrm{h}$ ) in relation to the protein content of the diet $(\mathrm{g} / \mathrm{kg})$. Fatty acid synthesis was determined from the rate of ${ }^{3} \mathrm{H}$ incorporation from ${ }^{3} \mathrm{H}_{2} \mathrm{O}$ into saponifiable rat liver lipids (for details, see p. 530). Values are means from four rats with their standard errors represented by vertical bars.

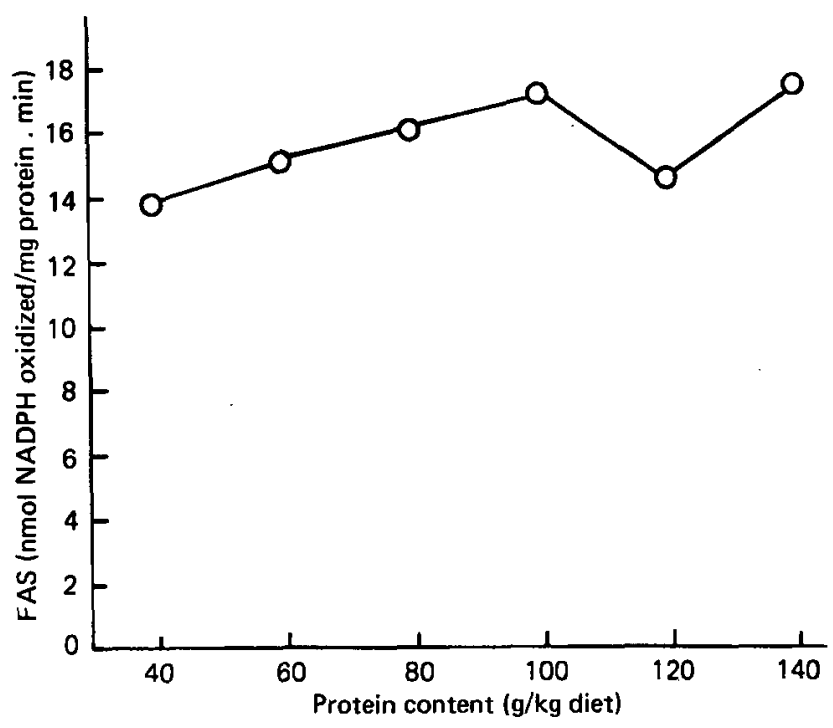

Fig. 3. Activity of fatty acid synthetase (FAS) in liver from rats given different amounts of protein in the diet. FAS was determined on a $100000 \mathrm{~g}$ supernatant fraction of rat liver homogenate by determining the malonyl-CoA-dependent oxidation of NADPH in the presence of acetyl CoA. Values are means for four rats. The standard error for each point lies within the diameter of the point. 


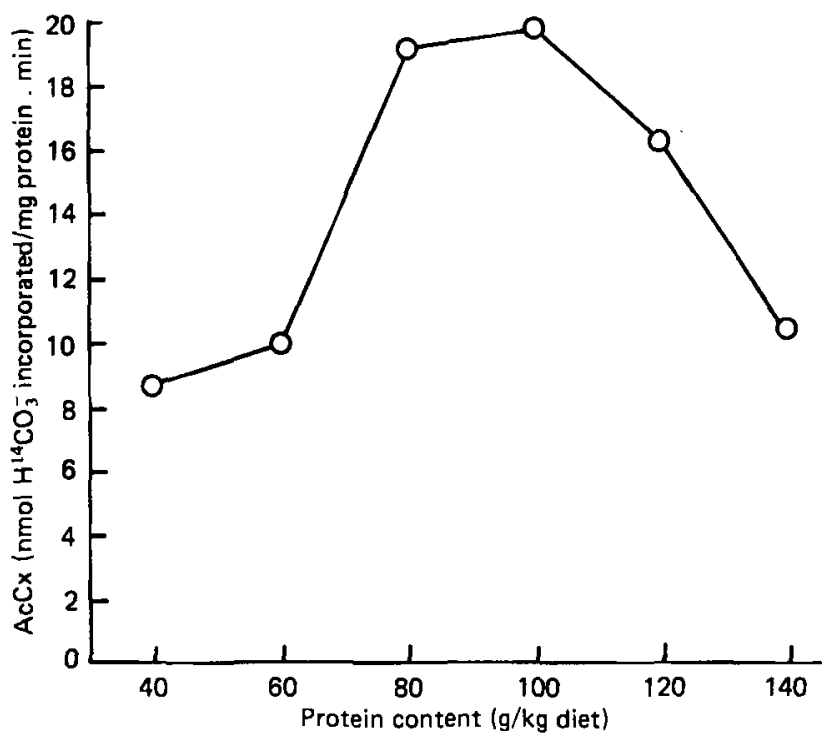

Fig. 4. Activity of acetyl CoA carboxylase $(E C 6.4 .1 .2 ; \mathrm{ACCx})$ in liver of rats given different amounts of protein in the diet. AcCx was determined on a $100000 \mathrm{~g}$ supernatant fraction of rat ljver homogenate by determining the incorporation of $\mathrm{H}^{14} \mathrm{CO}_{3}$ into acid-stable material. Values are means for four rats. The standard error lies within the diameter of each point.

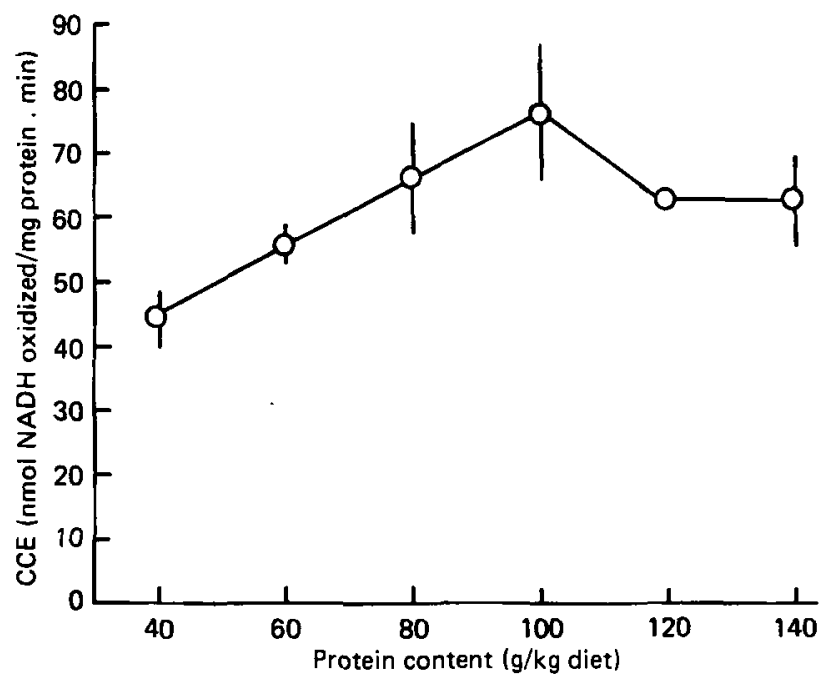

Fig. 5. Activity of citrate cleavage enzyme ( $E C$ 4.1.3.8; $C C E)$ in liver of rats given different amounts of protein in the diet. CCE was determined on a $100000 \mathrm{~g}$ supernatant fraction of rat liver homogenate by determining the rate of NADH oxidation in the presence of citrate and added malate dehydrogenase $(E C$ 1.1.1.37). Values are means of four rats with their standard errors represented by vertical bars. 


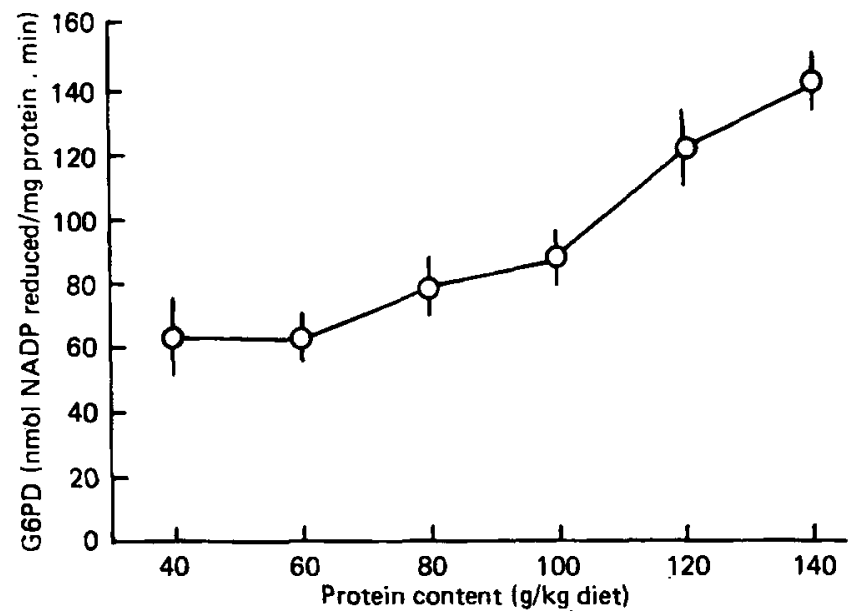

Fig. 6. Activity of glucose-6-phosphate dehydrogenase (EC 1.1.1.49; G6PD) in liver from rats given different amounts of protein in the diet. G6PD was determined on a $100000 \mathrm{~g}$ supernatant fraction of rat liver homogenate by determining the glucose-6-phosphate-dependent reduction of NADP. Values are means of four rats with their standard errors represented by vertical bars.

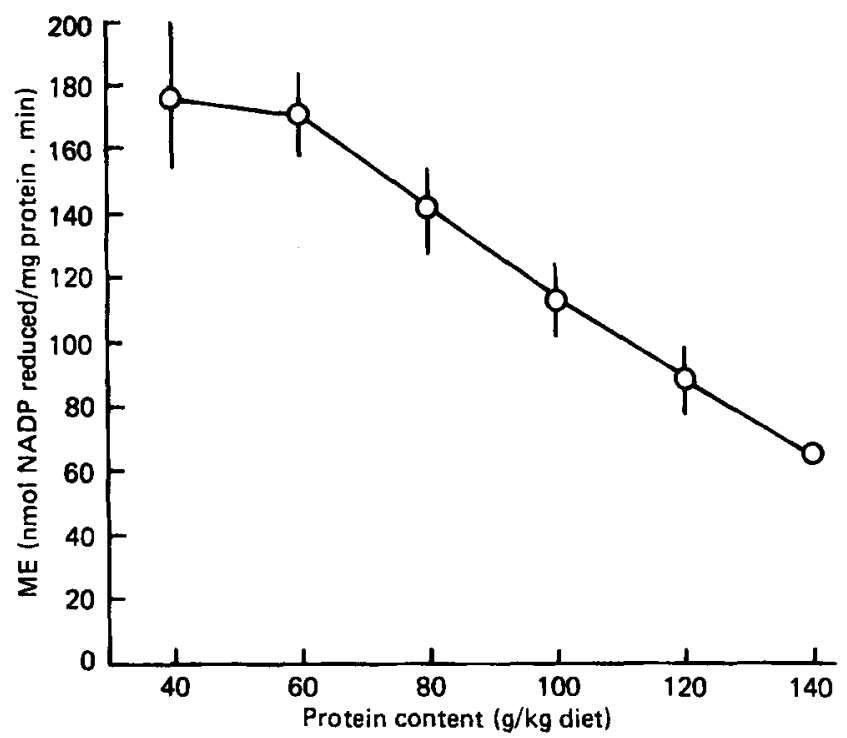

Fig. 7. Activity of malic enzyme ( $E C$ 1.1.1.40; ME) in liver from rats given different amounts of protein in the diet. ME was determined on a $100000 \mathrm{~g}$ supernatant fraction of rat liver homogenate by determining the malate-dependent reduction of NADP. Values are means of four rats with their standard errors represented by vertical bars. 


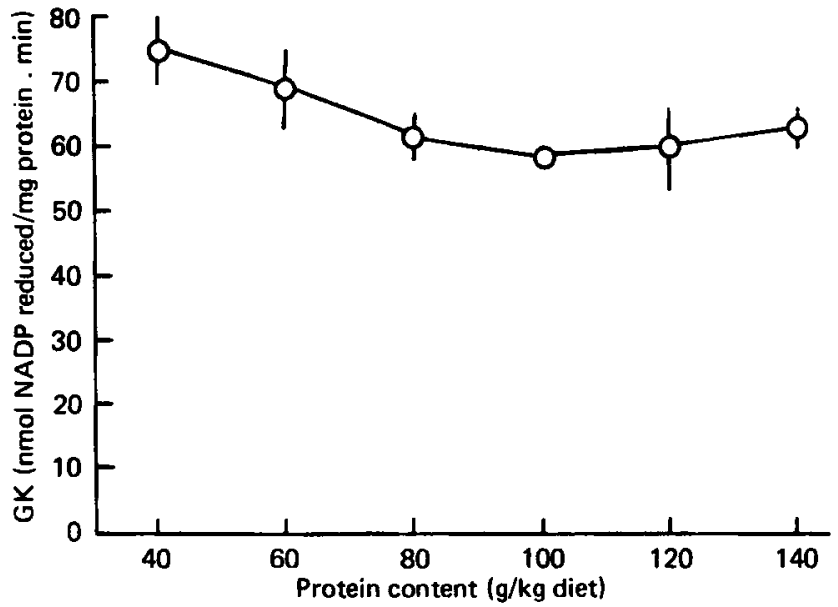

Fig. 8. Activity of glucokinase ( $E C 2.7 .1 .2 ; \mathrm{GK}$ ) in liver from rats given different amounts of protein in the diet. GK was determined on a $100000 \mathrm{~g}$ supernatant fraction of rat liver homogenate by determining the glucose-dependent reduction of NADP. The assay medium contained added glucose6-phosphate dehydrogenase $(E C$ 1.1.1.49). Values were corrected for hexokinase $(E C 2.7 .1 .1)$. Values are means for four rats with their standard errors represented by vertical bars.

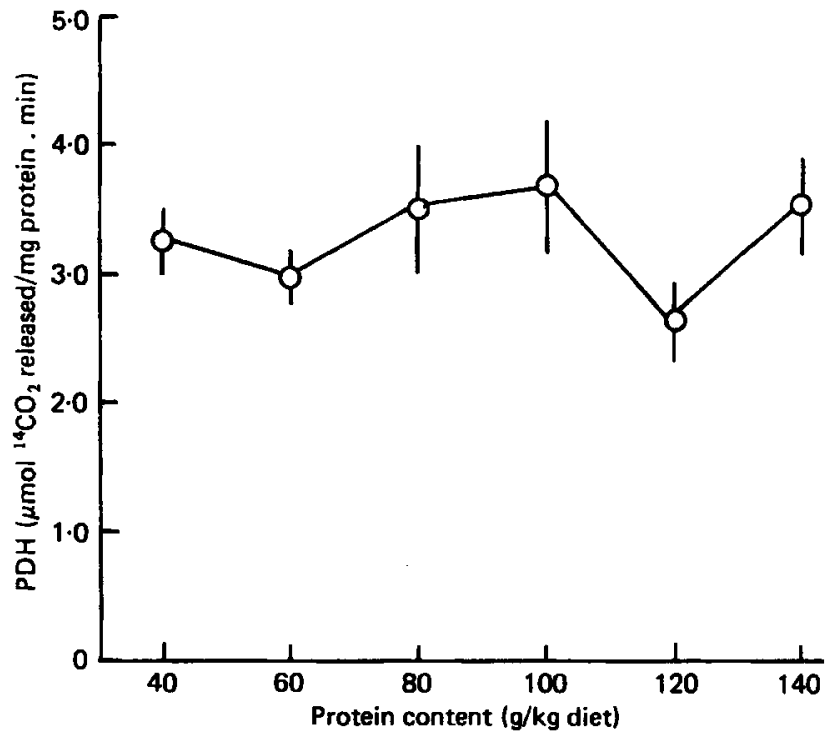

Fig. 9. Activity of pyruvate dehydrogenase (PDH) in liver from rats given different amounts of protein. $\mathrm{PDH}$ was determined in a rat liver homogenate by determining the release of ${ }^{14} \mathrm{CO}_{2}$ from $\left[1{ }^{14} \mathrm{C}\right]$ pyruvic acid. Values are means of four rats with their standard errors represented by vertical bars. 


\section{DISCUSSION}

The results shown in Table 1 and Fig. 1 confirm the well-known relationship between the level of dietary protein and animal weight gain (Barnes et al. 1946; Hegsted \& Chang, 1965). Optimum growth was attained at $100 \mathrm{~g}$ casein $/ \mathrm{kg}$ in the diet, a value slightly lower than the $120 \mathrm{~g}$ protein $/ \mathrm{kg}$ given as the requirement for growth in the rat (US National Research Council, 1978). The slightly higher growth rate observed in rats given $120 \mathrm{~g}$ protein $/ \mathrm{kg}$ was not statistically significant.

The balance of the results in Figs. 2-9 represent the first report of the correlation of a number of 'lipogenic' enzymes and lipogenesis with dietary protein in a growing animal.

Fatty acid synthesis (in vivo) tended to increase with increasing dietary protein up to $120 \mathrm{~g}$ protein $/ \mathrm{kg}$. This is in contrast to the findings of investigators who fed higher levels of dietary protein. Yeh \& Leveille (1969) found that increasing dietary protein from 150 to $350 \mathrm{~g} / \mathrm{kg}$ depressed in vitro hepatic fatty acid synthesis by approximately $75 \%$ in growing chicks. Stark et al. (1975) were unable to observe any difference in hepatic fatty acid synthesis (in vivo) in rats given a 5 or $180 \mathrm{~g}$ lactalbumin/ $/ \mathrm{kg}$ diet for $21 \mathrm{~d}$. Masoro et al. (1950) reported a greatly-diminished capacity for rat liver slices from rats given a $820 \mathrm{~g}$ casein $/ \mathrm{kg}$ diet to convert glucose to fatty acids compared to rats given a $220 \mathrm{~g}$ casein $/ \mathrm{kg}$ diet. Cohen \& Teitelbaum (1966) observed an increase in rat liver fatty acid synthesis when the dietary protein was reduced from 180 to $110 \mathrm{~g} / \mathrm{kg}$ whether the carbohydrate fed was sucrose or starch. From our results and those cited previously, it would appear that hepatic fatty acid synthesis increases with increasing dietary protein levels, reaches a maximum and then declines with further increases in protein in the diet.

Rates of synthesis usually, but not always, parallel the level of the associated enzymes. An examination of Figs. 2-9 shows that FAS, AcCx, CCE and G6PD activities tended to increase with increasing dietary protein. Fatty acid synthesis increased up to $100 \mathrm{~g} / \mathrm{kg}$ dietary protein at which point it levelled off. This is in agreement with the findings of Stark et al. (1975) who found that rats given $180 \mathrm{~g}$ casein $/ \mathrm{kg}$ had higher levels of liver FAS than those given $5 \mathrm{~g}$ casein $/ \mathrm{kg}$.

$\mathrm{AcCx}$, believed by many to be the major regulatory enzyme for fatty acid synthesis (Volpe \& Vagelos, 1976), exhibited a close correlation with synthesis measured (in vivo). It generally increased to the $100 \mathrm{~g}$ protein $/ \mathrm{kg}$ level and dropped drastically at 120 and $140 \mathrm{~g} / \mathrm{kg}$. CCE provides acetyl $\mathrm{CoA}$ in the cytoplasm for fatty acid biosynthesis from intramitochondriallygenerated citrate. The changes observed in CCE were not great but it tended to increase up to $100 \mathrm{~g}$ dietary protein $/ \mathrm{kg}$ and decline slightly above that level. Stark et al. (1975) observed no difference in CCE between rats given 180 or $5 \mathrm{~g}$ casein $/ \mathrm{kg}$. They report (no values presented) that after an extended period of time CCE is lower in the animals given $5 \mathrm{~g}$ casein $/ \mathrm{kg}$.

G6PD is the first enzyme in the pentose phosphate pathway which provides NADPH for fatty acid synthesis. G6PD steadily increased over the range of protein fed. This is similar to the finding of Peret et al. (1975) who fed adult rats diets containing $100-700 \mathrm{~g}$ casein $/ \mathrm{kg}$ for $23 \mathrm{~d}$ and found that G6PD increased as the protein level increased. However, Stark $\boldsymbol{e} t$ al. (1975) were unable to detect any change in G6PD in rats who were given $180 \mathrm{~g}$ casein/ $/ \mathrm{kg}$ and then switched to $5 \mathrm{~g}$ casein $/ \mathrm{kg}$ for $8 \mathrm{~d}$. Vaughan \& Winders (1964) fed carbohydrate-free diets containing $400-900 \mathrm{~g}$ casein $/ \mathrm{kg}$ to rats and found that hepatic G6PD increased with increases in dietary protein. Schimke (1962) fed either young (50-60 g) or older (140-150 g) rats diets containing 150,300 or $600 \mathrm{~g}$ casein/ $/ \mathrm{kg}$ and found that G6PD increased with increasing protein for rats in either age-group.

The total activity of PDH was not related to the dietary protein intake. We measured PDH in its fully-active form. PDH activity is regulated by a phosphorylationdephosphorylation mechanism and the percentage which is active can be altered by dietary 
manipulation (Wieland et al. 1972). The possibility remains that the percentage of PDH in the active form varied under the dietary conditions of these experiments.

GK activity decreased slightly but not significantly from 40 to $80 \mathrm{~g}$ protein $/ \mathrm{kg}$ and remained relatively constant at higher levels of protein.

The participation of ME in lipogenesis due to its ability to generate NADPH has been reported under a variety of conditions (for reviews, see Romsos \& Leville, 1974a; Frenkel, 1975). In general, (Gibson et al. 1972) FAS, G6PD, AcCx and ME have been observed to rise and fall in concert. Yeh \& Leveille (1969) found that increasing dietary protein from 150 to $350 \mathrm{~g} / \mathrm{kg}$ depressed fatty acid synthesis and ME activity by approximately $75 \%$ in liver from growing chicks. However, a number of investigators have found a dissociation of ME from G6PD or fatty acid synthesis, or both.

Vaughan \& Winders (1964) fed carbohydrate-free diets containing 400-900 g protein $/ \mathrm{kg}$ to rats and observed that while G6PD increased with increasing protein there was no consistent change in ME. Schimke (1962) found that while G6PD increased 5-6-fold in rats fed $150-600 \mathrm{~g}$ casein $/ \mathrm{kg} \mathrm{ME}$ increased only approximately $10-15 \%$. Frenkel and associates studied the adaptation that occurs when rats adapted to a $180 \mathrm{~g}$ protein $/ \mathrm{kg}$ diet are changed to one containing $5 \mathrm{~g}$ protein $/ \mathrm{kg}$ and observed that while $\mathrm{ME}$ was increased by this treatment there was no correlation between $M E$ and fatty acid synthesis either in vivo or in vitro, isocitrate dehydrogenase (EC 1 1 1 1 .42), FAS, G6PD or CCE. (Frenkel et al. 1972; Stark \& Frenkel, 1974; Frenkel, 1975; Stark et al. 1975). Peret et al. (1975) fed adult rats diets containing $100-700 \mathrm{~g}$ protein/ $\mathrm{kg}$. Increasing the protein produced a progressive fall in the activities of $\mathrm{ME}$ and a progressive increase in G6PD. Our results showing a decline in ME while AcCx, FAS, G6PD and fatty acid synthesis (in vivo) increase clearly demonstrate that $\mathrm{ME}$ is not always closely associated with lipogenesis. It appears that when low-protein diets are fed to growing rats the NADPH needed for fatty acid synthesis is generated primarily by ME. As the level of protein is increased, the contribution of $\mathrm{ME}$ is reduced while that of the phosphogluconate pathway becomes more important.

In conclusion, we have examined the effect of the level of dietary protein on fatty acid synthesis (in vivo) and on the activity of a number of enzymes in the liver of young, growing rats. We have observed that there is a clear dissociation of changes in activity of $\mathrm{ME}$ from fatty acid synthesis and from changes in activity of FAS, G6PD, CCE and AcCx. These findings reinforce the conclusions of Stark et al. (1975) that the role of ME is not limited only to its function as a lipogenic enzyme.

This work was supported by the MRC of Canada.

REFERENCES

Barnes, R. H., Bates, M. J. \& Maack, J. E. (1946). J. Nutr. 32, 535.

Bruckdorfer, K. R., Khan, I. H. \& Yudkin, J. (1972). Biochem. J. 129, 439.

Clarke, S. D., Romsos, D. R. \& Leveille, G. A. (1977 a). J. Nutr. 107, 1170.

Clarke, S. D., Romsos, D. R. \& Leveille, G. A. (1977b). J. Nutr. 107, 1277.

Clarke, S. D., Romsos, D. R. \& Leveille, G. A. (1977c). J. Nutr. 107, 1468.

Cohen, A. M. \& Teitelbaum, A. (1966). Israel J. med. Sci. 2, 727.

Frenkel, R. (1975). Curr. Topics Cell. Reg. 9, 157.

Frenkel, R., Stark, M. J. \& Stafford, J. (1972). Biochem. Biophys. Res. Commun. 49, 1684.

Gibson, D. M. \& Hubbard, D. D. (1960). Biochem. Biophys. Res. Commun. 3, 351.

Gibson, D. M., Lyons, R. T., Scott, D. F. \& Muto, Y. (1972). Adv. Enzyme Reg. 10, 187.

Goa, J. (1953). Scand. J. clin. Lab Invest. 5, 218.

Gove, C. D. \& Hems, D. A. (1978). Biochem. J. 170, 1.

Hegsted, D. M. \& Chang, Y-O. (1965). J. Nutr. 85, 159.

Hill, R., Webster, W. W., Linazasoro, J. M. \& Chaikoff, I. L. (1960). J. Lipid Res. 1, 150.

Lohr, G. W. \& Walker, H. O. (1971). In Methods of Enzymatic Analysis, vol. 2, p. 636 [H. V. Bergmeyer, editor].

New York: Academic Press.

Lowenstein, J. M. (1971). J. biol. Chem. $246,629$.

Masoro, E. J., Chaikoff, I. L., Chernick, S. S. \& Felts, J. M. (1950). J. biol. Chem. 185, 845. 
National Research Council (1978). Nutrient Requirements of Laboratory Animals 3rd ed. Washington, DC: National Research Council.

Peret, J., Chanes, M., Cota, J. \& Macaire, I. (1975). J. Nutr. 105, 1525.

Pilkis, S. J. (1975). Meth. Enzym. 42, 31.

Romsos, D. R. \& Leveille, G. A. (1974a). Adv. Lipid Res. 12, 97.

Romsos, D. R. \& Leveille, G. A. (1974b). Biochim. biophys. Acta 360, 1.

Schimke, R. T. (1962). J. biol. Chem. 237, 459.

Srere, P. A. (1959). J. biol. Chem. 234, 2544.

Stark, M. J. \& Frenkel, R. (1974). Life Sci. 14, 1563.

Stark, M. J., Thompson, B. \& Frenkel, R. (1975). Archs. Biochem. Biophys. 166, 174.

Steel, R. G. D. \& Torrie, J. H. (1960). Principles and Procedures of Statistics. New York: McGraw Hill.

Taylor, S. I., Muckherjee, C. \& Jungas, R. L. (1973). J. biol. Chem. 248, 73.

Triscari, J., Hamilton, H. G. \& Sullivan, A. C. (1978). J. Nutr. 108, 815.

Vaughan, D. A. \& Winders, R. L. (1964). Am. J. Physiol. 206, 1081.

Volpe, J. J. \& Vagelos, P. R. (1976). Physiol. Rev. 56, 399.

Walajtys, E. I., Gottesman, D. P. \& Williamson, J. R. (1974). J. biol. Chem. 249, 1857.

Wieland, O. H., Patzelt, C. \& Loffler, G. (1972). Eur. J. Biochem. 26, 426.

Yeh, Y. Y. \& Leveille, G. A. (1969). J. Nutr. 98, 356.

Yeh, Y. Y., Leveille, G. A. \& Wiley, J. H. (1970). J. Nutr. 100, 917. 